\title{
Pendekatan Open-Ended dalam Membelajarkan Kemampuan Koneksi Matematis Siswa
}

\author{
Roslian Lubis $^{1 *}$, Toharuddin Harahap ${ }^{2}$, dan Dwi Putria Nasution ${ }^{3}$ \\ Pendidikan Matematika, Institut Pendidikan Tapanuli Selatan \\ Jalan Stn. Mhd. Arif Kel. Batang Ayumi Jae, Padangsidimpuan, Sumatera Utara, Indonesia \\ 1*roslianlubis84@gmail.com; 2toharuddin323@gmail.com \\ Guru SMA Negeri 2 Padangsidimpuan \\ Jalan Merdeka No. 186, Padangsidimpuan, Sumatera Utara, Indonesia \\ 3putridwinst@gmail.com
}

Artikel diterima: 30-07-2019, direvisi: 21-09-2019, diterbitkan: 30-09-2019

\begin{abstract}
Abstrak
Masalah dalam penelitian ini adalah rendahnya Kemampuan Koneksi Matematis (KKnM) siswa dan pembelajaran terlaksana cenderung bersifat konvensional. Suatu alternatif mengoptimalkan kemampuan bermatematika siswa dan perbaikan proses pembelajaran yaitu mempertimbangkan penerapan pendekatan pembelajaran dengan pendekatan open-ended. Penelitian ini bertujuan untuk mendeskripsikan apakah terdapat interaksi Kemampuan Awal Matematika (KAM) dan gender dengan pendekatan pembelajaran dalam membelajarkan KKnM siswa. Penelitian merupakan penelitian eksperimen semu dengan rancangan Nonequivalent Control Group Design. Instrumen yang digunakan adalah essay test KKnM siswa. Populasi penelitian adalah siswa kelas VII SMP Negeri 5 Padangsidimpuan sebanyak 9 rombongan belajar dan sampel penelitian adalah siswa kelas VII-5 dan VII-6 yang masing-masing kelas berjumlah 28 siswa. Hasil penelitian melalui uji hipotesis dengan anava dua jalur menunjukkan tidak terdapat interaksi antara KAM dengan pendekatan pembelajaran dalam membelajarkan KKnM siswa dan tidak terdapat interaksi antara gender dengan pendekatan pembelajaran dalam membelajarkan KKnM siswa.

Kata Kunci: Open-ended, KKnM, Pendekatan Pembelajaran, KAM, Gender.
\end{abstract}

\section{The Open-Ended Approach in Learning Mathematical Connection Ability of Middle School Students}

\begin{abstract}
The problem in this study was the low of students' Mathematical Connection Ability (MCA) and learning that tends to be conventional. An alternative to optimizing students' mathematical abilities and improving the learning process is to consider the applying of a learning approach to the openended approach. This study aims to describe is there any interaction between the Mathematical Prior Ability (MPA) and gender with the learning approach in teaching the students' MCA. The research was quasi-experimental research with Nonequivalent Control Group Design. The used instrument was the students' mathematical connection ability essay test. The population of the research was 7 thgrade students of SMP Negeri 5 Padangsidimpuan with 9 groups study and the sample of the research were students of grades VII-5 and VII-6, where the number of each class was 28 students. The research results by hypothesis testing with two-way Anava showed that there was no interaction between the MPA with the learning approach in teaching the students' MCA and there was no interaction between gender with the learning approach in teaching the student' MCA.

Keyword: Open-ended, MCA, Learning Approach, MPA, Gender.
\end{abstract}




\section{Pendahuluan}

Matematika merupakan ilmu yang memiliki keterkaitan antara satu materi dengan materi lainnya. Pemahaman terhadap materi matematika untuk suatu materi selanjutnya berkaitan dengan pemahaman kita terhadap materi sebelumnya. Lampiran Permendikbud Nomor 58 (Mendikbud, 2014) tentang kurikulum 2013 SMP/MTs mengungkapkan karakteristik matematika diantaranya adalah antara satu materi matematika dengan materi lainnya terdapat keterkaitan dan materi matematika tersebut dapat diterapkan dibidang ilmu lain.

Kemampuan Koneksi Matematis (KKnM) merupakan kemampuan yang penting dikembangkan dalam pembelajaran. Pemanfaatan konsep keterkaitan dapat membelajarkan kemampuan bermatematika siswa dalam memecahkan permasalahan yang dihadapi siswa dengan baik dalam pembelajaran maupun dalam kehidupan sehari-hari. Apriyono (2014) mengungkapkan melalui koneksi matematika pesrta didik akan memiliki wawasan dan pemikiran yang semakin terbuka terhadap matematika, tidak hanya terfokus pada topik tertentu yang sedang dipelajari, sehingga akan menimbulkan sikap positif terhadap matematika itu sendiri.

KKnM disebut juga kemampuan mengaitkan konsep dalam matematika yang merupakan salah satu kemampuan dasar yang harus dimiliki oleh siswa
(Sugiarti \& Basuki, 2014). Selanjutnya Sritresna (2015) mengungkapkan bahwa koneksi matematis akan membuat pelajaran matematika lebih dipahami lebih bermakna, membantu siswa untuk mengingat suatu konsep/materi pelajaran serta menerapkannya secara tepat dalam situasi pemecahan masalah, memungkinkan siswa untuk menerapkan konsep/materi matematika pada pelajaran lain atau dalam kehidupan sehari-hari.

Koneksi matematika membantu siswa untuk mengembangkan sudut pandangnya terhadap matematika sebagai bagian yang memiliki suatu kesatuan daripada sebagai sekumpulan topik, serta mengakui adanya tujuan yang sama dari penerapan konsep yang dilakukan baik di dalam kelas maupun di luar kelas (NCTM, 2000). Dengan demikian koneksi matematika merupakan suatu kemampuan dalam mengaitkan/menghubungkan berbagai konsep/materi matematika yang diterapkan dengan tujuan tertentu .

Untuk mengukur KKnM Sugiman (2008) mengungkapkan empat aspek yang perlu diperhatikan yaitu: 1) koneksi inter topik matematika yang mengaitkan antar konsep atau prinsip dalam satu topik tertentu; 2) koneksi antar topik dalam matematika yang mengaitkan antara materi dalam topik tertentu dengan materi dalam topik lainnya; 3) koneksi antara materi matematika dengan ilmu pengetahuan di luar pelajaran matematika, dan; 4) koneksi dengan kehidupan sehari-hari yang mungkin dijumpai peserta didik. Selanjutnya

Mosharafa: Jumal Pendidikan Matematika Volume 8, Nomor 3, September 2019 Copyright $\odot 2019$ Mosharafa: Jurnal Pendidikan Matematika 
Anandita (2015) mengungkapkan indikator yang digunakan untuk menganalisis KKnM siswa SMP adalah: Menemukan hubungan dari representasi tentang konsep dan prosedur, memahami hubungan antar topik, menggunakan matematika dalam penyelesaian masalah sehari-hari, memahami representasi konsep yang ekuivalen, menemukan hubungan prosedur yang ekuivalen, menggunakan koneksi antara matematika dengan matematika sendiri maupun dengan ilmu yang lainnya.

Berdasarkan uraian teori yang disampaikan sebelumnya tampak bahwa KKnM penting dikuasai oleh siswa. Namun berbagai hasil penelitian menunjukkan bahwa KKnM siswa rendah dalam pembelajaran. Penelitian Nugraha (2018) dapat disimpulkan bahwa KKnM siswa SMP masih rendah terutama dalam mengaplikasikan dalam kehidupan seharihari. Hal ini dikarenakan siswa sulit untuk menjelaskan alasan pada setiap langkah penyelesaiannya. Sejalan dengan penelitian Latipah \& Afriansyah (2018), rendahnya KKnM mengakibatkan dilakukannya penelitian dengan solusi pembelajaran CTL dan RME. Selanjutnya, hasil penelitian Sudirman, Cahyono, \& Kadir (2018) menunjukkan bahwa KKnM siswa rendah, hanya mencapai 36\%. KKnM siswa laki-laki sebesar 29\% dan siswa perempuan 40\%. Penyebab rendahnya KKnM siswa SMP pesisir ini adalah rendahnya pemahaman konsep matematis siswa.
Hasil observasi peneliti ketika melakukan ujicoba soal KKnM pada salah satu SMP di kota Padangsidimpuan ditemukan siswa kurang mampu mengaitkan materi yang dipahaminya terhadap pemecahan masalah. Melalui analisis hasil tes diperoleh ketuntasan siswa sebesar 46\% dengan KKM 76. Tingkat ketuntasan KKnM siswa tersebut berada dalam kategori rendah dan pembelajaran yang terjadi cendrung bersifat konvensional dan berpusat pada guru sebagai sumber belajar. Dominasi aktivitas guru dalam pembelajaran mengakibatkan menurunnya aktivitas siswa dalam pembelajaran yang berakibat pada rendahnya kemampuan bermatematika siswa (Ahmad \& Nasution, 2018).

Salah satu pendekatan pembelajaran yang sejalan dengan karakteristik matematika dan harapan kurikulum yang berlaku pada saat ini adalah pendekatan pembelajaran open-ended. Pembelajaran dengan pendekatan open-ended di kelas akan memberi kesempatan kepada siswa untuk berpikir dengan bebas sesuai dengan minat dan kemampuan siswa sehingga aktivitas siswa di kelas penuh dengan kebebasan dan penuh dengan ideide matematika yang pada gilirannya akan memacu kemampuan berpikir tingkat tinggi siswa (Andriani \& Madio, 2013). Pendekatan open-ended memberikan kesempatan kepada siswa untuk memperoleh pengetahuan, pengalaman, menemukan, mengenali, dan memecahkan masalah dengan beberapa 
teknik serta pendekatan ini diharapkan dapat menjadi fasilitator dalam mengembangkan dan merangsang $\mathrm{KKnM}$ siswa.

Pendekatan open-ended bertujuan agar siswa mengelaborasi ide-ide kreatif dan pola pikir matematis terhadap masalah yang bersifat terbuka serta siswa terbiasa untuk melakukan penyelidikan dengan berbagai cara dalam memecahkan masalah (Salamah \& Amelia, 2019). Selanjutnya Suherman et al., (2001) mengungkapkan pendekatan Open-ended menjanjikan suatu kesempatan kepada siswa untuk menginvestigasi berbagai strategi dan cara yang diyakininya sesuai dengan kemampuannya mengelaborasi masalah. Melalui pendekatan open-ended siswa termotivasi untuk belajar aktif, penuh semangat dan siswa akan semakin terbuka terhadap matematika, serta akan menyadari manfaat matematika.

Penelitian terdahulu memberi informasi bahwa dengan menerapkan pendekatan open-ended beberapa penelitian menunjukkan hasil yang memuaskan. Hasil penelitian Maryani, Marlina, \& Amelia (2019) menunjukan bahwa semua indikator kemampuan berpikir kreatif matematik yang meliputi kelancaran, kelenturan, keaslian dan kerincian mengalami peningkatan yang signifikan melalui pembelajaran open-ended. Selanjutnya penelitian yang dilakukan oleh Sabar (2017) menunjukkan hasil belajar matematika siswa dengan model Problem Based Learning (PBL) dan pendekatan open-ended berada pada kategori tinggi; 402 dan aktivitas siswa berada pada kategori sangat aktif. Selanjutnya penelitian yang dilakukan Andriani \& Madio (2013) menunjukkan kemampuan berpikir reflektif antara siswa yang mendapatkan pendekatan open-ended lebih baik dibandingkan dengan pendekatan konvensional.

Analisis terhadap penelitian mengimplikasikan bahwa pendekatan open-ended dapat dijadikan guru sebagai salah satu alternatif untuk meningkatkan kemampuan bermatematika siswa tidak terkecuali KKnM siswa. Dalam peningkatan kemampuan ini ada faktor yang bisa saja berpengaruh dalam membelajarkan KKnM tersebut. Faktor tersebut antara lain kemampuan awal bermatematika siswa dan perbedaan jenis kelamin (gender). Interaksi antara kemampuan awal dan gender dengan pendekatan pembelajaran dalam membelajarkan KKnM dijadikan sebagai masalah dalam penelitian ini. Adapun tujuannya yaitu untuk mendeskripsikan apakah terdapat interaksi Kemampuan Awal Matematika (KAM) dan gender dengan pendekatan pembelajaran dalam membelajarkan KKnM siswa.

\section{Metode}

Penelitian ini merupakan penelitian eksperimen semu yang bertujuan untuk mendeskripsikan interaksi Kemampuan Awal Matematika (KAM) dan gender dengan pendekatan pembelajaran dalam membelajarkan Kemampuan Koneksi Matematis (KKnM) siswa. Penelitian menggunakan quasi-ekperimental design 
yang merupakan desain yang mempunyai kelompok kontrol tetapi tidak dapat berfungsi sepenuhnya mengontrol variabel-variabel luar yang mempengaruhi pelaksanaan eksperimen (Sugiyono, 2016). Rancangan yang digunakan adalah Nonequivalent Control Group Design. Pupulasi penelitian adalah siswa kelas VII SMP Negeri 5 Padangsidimpuan sebanyak 9 rombongan belajar. Selanjutnya diangkat sampel penelitian sebanyak 2 kelas yang dijadikan sebagai kelas eksperimen dan kelas kontrol dengan pertimbangan bahwa jumlah siswa sama dan tingkat kemampuan siswa setara. Sampel penelitian adalah siswa kelas VII-5 sebagai kelas eksperimen dan siswa kelas VII-6 sebagai kelas kontrol dengan jumlah siswa masing-masing kelas adalah 28 orang. Rancangan penelitian adalah sebagai berikut:

\begin{tabular}{ccc}
\hline $0_{1}$ & $X$ & $O_{2}$ \\
\hline $0_{3}$ & & $0_{4}$
\end{tabular}

Keterangan:

$\mathrm{O}_{1}$ : Pretest kelas eksperimen

$\mathrm{O}_{2}$ : Posttest kelas eksperimen

$\mathrm{O}_{3}$ : Pretest kelas kontrol

$\mathrm{O}_{4}$ : Posttest kelas kontrol

$X$ : Pendekatan open-ended

Data penelitian diperoleh melalui uji pretest dan posttest. Soal tes yang diberikan kepada siswa adalah soal KKnM siswa masing-masing sebanyak 5 butir untuk pretest dan 5 butir untuk posttest. Soal yang digunakan dalam tes adalah soal yang yang telah divalidasi oleh validator dengan kriteria penilaian validasi isi adalah valid, bahasa soal dapat dipahami dan dengan kesimpulan penilaian 3 orang validator adalah tanpa revisi. Selanjutnya berdasarkan ujicoba instrumen tes KKnM sebanyak 7 soal untuk pretest, diperoleh 5 butir tes yang memiliki nilai validitas sedang. Indeks reliabilitas berada dalam kategori sedang. Selanjutnya dari 7 butir soal posttest yang diujicobakan terdapat 5 butir soal yang memenuhi validitas sedang dengan indeks reliabilitas 0,43 yang berada pada kategori sedang.

Pretest dan posttest diujikan kepada siswa dalam bentuk soal essay test KKnM siswa masing-masing sebanyak lima soal. Indikator tes KKnM siswa adalah: 1) memahami dan menerapkan hubungan antar berbagai konsep/ materi matematika; 2) menerapkan konsep/ materi matematika dalam suatu permasalahan dan ; 3) menerapkan konsep/ materi matematika dalam memecahkan permasalahan sehari-hari. Perolehan nilai pretest dijadikan sebagai dasar pengelompokan KAM siswa dan nilai posttest dijadikan salah satu faktor penentu dalam penentuan terdapat atau tidaknya interaksi KAM dan gender dengan pendekatan pembelajaran dalam membelajarkan KKnM siswa.

Awal dalam penelitian adalah pemberian soal pretest kepada siswa. Soal pretest yang diujikan bertujuan untuk mendapatkan deskripsi KAM, selanjutnya disebut tes KAM. Proses pengklasifikasian KAM meliputi tinggi, sedang dan rendah yang diklasifikasikan dengan aturan pada table 1 berikut. 
Selanjutnya kelas eksperimen dan kontrol masing masing diberi perlakuan 4 kali pertemuan dengan tiap pertemuan dilakukan dengan durasi $2 \times 40$ menit. Materi yang diajarkan adalah materi bangun datar pada pokok bahasan persegi dan persegi panjang. Penerapan pembelajaran dengan pendekatan openended dengan tahapan: 1) Mengorganisasikan siswa dalam kegiatan pembelajaran dengan membentuk kelompok belajar siswa dengan yang beranggotakan dari 4-6 orang; 2) Menyajikan masalah terbuka kepada kelompok siswa dalam bentuk lembar aktivitas siswa; 3) Membimbing dan mengarahkan siswa dalam memecahkan permasalahan yang disajikan hingga penyelesaian diperoleh dengan beragam cara; 4) Menyajikan dan membandingkan hasil karya masing-masing kelompok di depan kelas; 5) Menyimpulkan materi/temuan yang diperoleh dalam kegiatan pembelajaran yang dipandu oleh guru. Selanjutnya melalui pendekatan model biasa (pendekatan konvensional) pembelajaran dilakukan dengan: 1) Guru menyajikan dan menjelaskan materi di depan kelas; 2) Menjelaskan contoh-

Tabel 1.

Kategori Klasifikasi KAM

\begin{tabular}{|c|c|}
\hline $\begin{array}{c}\text { Kelompok } \\
\text { Kemampuan }\end{array}$ & Kriteria \\
\hline Tinggi & Siswa yang memiliki pretest $\geq \bar{x}+\mathrm{s}$ \\
\hline Sedang & $\begin{array}{l}\text { Siswa yang memiliki pretest diantara } \\
\qquad \bar{x}-\mathrm{s} \text { dan } \bar{x}+\mathrm{s}\end{array}$ \\
\hline Rendah & $\begin{array}{l}\text { Siswa yang memiliki pretest } \leq x \text { - s } \\
\text { Sumber modivikasi (Saragih, 2007) }\end{array}$ \\
\hline
\end{tabular}

404 contoh; 3) Memberikan soal latihan. Setelah perlakuan dengan pendekatan open-ended dan pendekatan konvensioanal terlaksana selanjutnya pada kelas eksperimen dan kelas kontrol diberikan posttest untuk melihat hasil akhir dari KKnM siswa.

Analisis data KKnM siswa dilakukan untuk menentukan apakah terdapat interaksi antara KAM (tinggi, sedang, rendah) dengan pendekatan pembelajaran dalam membelajarkan KKnM siswa dan untuk menentukan apakah terdapat interaksi antara gender (laki-laki dan perempuan) dengan pendekatan pembelajaran dalam membelajarkan KKnM siswa. Analisis hasil penelitian dilakukan dengan uji anava dua jalur. Hipotesis yang diajukan terkait KAM, pendekatan pembelajaran dan $\mathrm{KKnM}$ siswa adalah sebagai berikut.

Ho: Terdapat interaksi antara KAM dengan pendekatan pembelajaran dalam membelajarkan KKnM siswa siswa.

Ha: Tidak terdapat interaksi antara KAM dengan pendekatan pembelajaran dalam membelajarkan KKnM siswa.

Selanjutnya hipotesis terkait dengan gender, pendekatan pembelajaran dan KKnM siswa dirumuskan sebagai berikut.

Ho: Terdapat interaksi antara gender dengan pendekatan pembelajaran dalam membelajarkan KKnM siswa.

Ha: Tidak terdapat interaksi antara gender dengan pendekatan pembelajaran dalam membelajarkan KKnM siswa.

Dengan kriteria tolak Ho jika signifikansi lebih besar dari 0,05. Selanjutnya untuk Mosharafa: Jurnal Pendidikan Matematika Volume 8, Nomor 3, September 2019 Copyright $\odot 2019$ Mosharafa: Jurnal Pendidikan Matematika 
dapat menggunakan uji anava dua jalur tersebut harus terlebih dahulu dapat diperlihatkan data yang digunakan homogen dan berdistribusi normal. Untuk menganalisis homogenitas data digunakan uji Test of Homogeneity of Variances levene statistic dan untuk menguji normalitas data digunakan uji statistik One-Sample Kolmogorov-Smirnov Test.

\section{Hasil dan Pembahasan}

\section{A. Hasil Penelitian}

Berdasarkan pengumpulan data di lapangan yang dilakukan pada kelompok sampel penelitian melalui pretest dan posttest diperolah data Kemampuan Koneksi Matematis (KKnM) siswa. Sebelum uji hipotesis dengan anava dua jalur terlebih dahulu dilakukan uji homogenitas dan normalitas. Berikut dibawah ini hasil analisis tentang hasil signifikansi uji homogenitas dengan uji Levene Statistic disajikan pada table 2 .

Perolehan nilai signifikansi (sig.) pretest $(0,59)$ dan posttest $(0,72)$ dari kelas eksperimen dan kelas kontrol berada diatas 0,05 dengan demikian disimpulkan

Tabel 2.

Indeks Signifikansi Homogenitas

\begin{tabular}{|cc|}
\hline Kelas & Sig. (2-tailed) \\
\hline Pretest & 0,59 \\
\hline Posttest & 0,72 \\
\hline
\end{tabular}

Tabel 3.

Indeks Signifikansi Normalitas

\begin{tabular}{|cc|}
\hline KKnM Siswa & Sig. (2-tailed) \\
\hline Pretest Eksperimen & 0,50 \\
\hline Posttest Eksperimen & 0,28 \\
\hline Pretest Kontrol & 0,40 \\
\hline Posttest Kontrol & 0,26 \\
\hline
\end{tabular}

bahwa bahwa data pretest dan posttest KKnM siswa kelas eksperimen dan kelas kontrol adalah mempunyai varian yang sama atau homogen.

Dengan memperhatikan tabel 3 dapat diamati bahwa nilai Asymp. Sig. (2-tailed) Pretest Eksperimen, Posttest Eksperimen, Pretest Kontrol, Posttest Kontrol berada diatas 0,05. Dengan demikian disimpulkan bahwa data pretest dan posttest KKnM siswa kelas eksperimen dan kelas kontrol adalah berdistribusi normal.

1. Interaksi KAM terhadap Pendekatan Pembelajaran

Kemampuan Awal Matematika (KAM) adalah tingkat kemampuan siswa dalam bermatematika sebelum diberikan pembelajaran. Berdasarkan perolehan data dari tes KAM dan pengklasifikasian berpedoman pada tabel 1 diperoleh kategori KAM siswa pada tabel 4 berikut.

Dari tabel 4 dapat diamati bahwa dari kelas dengan pendekatan open-ended dan pendekatan konvensional siswa yang berada pada kategori tinggi sebanyak 7 orang, kategori sedang sebanyak 41 orang dan pada kategori rendah adalah sebanyak 8 orang. Berdasarkan analisis varian dua

Tabel 4.

Kategori Kelompok KAM

\begin{tabular}{cccc|}
\hline Pendekatan & Tinggi & Sedang & Rendah \\
\hline Open-ended & 3 & 20 & 5 \\
\hline Konvensional & 4 & 21 & 3 \\
\hline Jumlah & 7 & 41 & 8
\end{tabular}

Tabel 5.

Perolehan intraksi pendekatan dengan KAM

\begin{tabular}{ccc}
\hline Variabel & F & Sig. \\
\hline $\begin{array}{c}\text { Pendekatan } \\
\text { Pembelajaran * KAM }\end{array}$ & 1,19 & 0,31 \\
\hline
\end{tabular}


jalur terhadap data KAM dan hasil posttest KKnM siswa kelas eksperimen dan kelas kontrol diperoleh data pada table 5 sebagai berikut.

Dari tabel 5 diperoleh nilai $F$ sebesar 1,19 dan nilai signifikansi $0,31>0,05$ yang berarti tolak $\mathrm{H}_{0}$ dan terima $\mathrm{H}_{\mathrm{a}}$ yang memberi simpulan bahwa tidak terdapat interaksi antara KAM dengan pendekatan pembelajaran (open-ended dan konvensional) dalam membelajarkan KKnM siswa. Hal tersebut dapat dilihat lebih jelasnya pada gambar 1 berikut.

Dari gambar 1 dapat diperhatikan kurva kelas eksperimen tidak bersinggungan dengan kurva kelas kontrol. Hal lebih memperjelas bahwa tidak terdapat interaksi antara KAM dengan pendekatan pembelajaran dalam membelajarkan KKnM siswa.

2. Interaksi Gender terhadap Pendekatan Pembelajaran

Gender adalah tingkat kemampuan berdasarkan jenis kelamin antara laki-laki dan perempuan. Laki-laki dan perempuan memiliki kemampuan pada tingkat masingmasing. Kategori kelompok laki-laki dan

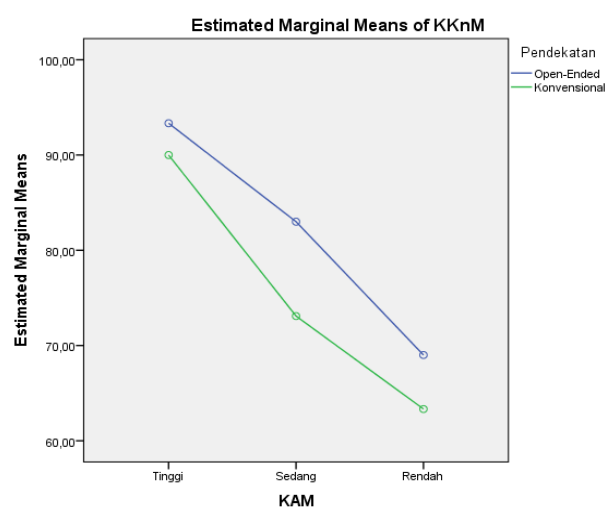

Gambar 1. Intraksi Pendekatan dengan KAM perempuan terdapat dalam tabel 6 berikut.

Dari tabel 6 diketahui bahwa pada kelas dengan pendekatan open-ended terdiri dari 15 siswa lak-laki dan 13 siswa perempuan. Selanjutnya siswa pada kelas dengan pendekatan konvensional terdiri dari 16 orang siswa laki-laki dan 12 orang siswa perempuan. Berdasarkan analisis varian dua jalur terhadap data gender, hasil posttest KKnM dari siswa kelas eksperimen dan kelas kontrol diperoleh data pada table 7 berikut.

Dari tabel 7 hasil analisis anava dua jalur diperoleh nilai $F$ sebesar 0,45 dan nilai signifikansi $0,50>0,05$ yang berarti tolak $\mathrm{H}_{0}$ dan terima $\mathrm{H}_{a}$ yang memberi

Tabel 6.

Kategori Kelompok Gender

\begin{tabular}{ccl}
\hline Pendekatan & Laki-laki & Perempuan \\
\hline Open-ended & 15 & 13 \\
\hline Konvensional & 16 & 12 \\
\hline Total & 31 & 25 \\
\hline
\end{tabular}

Tabel 7.

Perolehan intraksi pendekatan dengan gender

\begin{tabular}{ccc}
\hline Variabel & $F$ & Sig. \\
\hline $\begin{array}{c}\text { Pendekatan } \\
\text { Pembelajaran * Gender }\end{array}$ & 0,45 & 0,50 \\
\hline
\end{tabular}

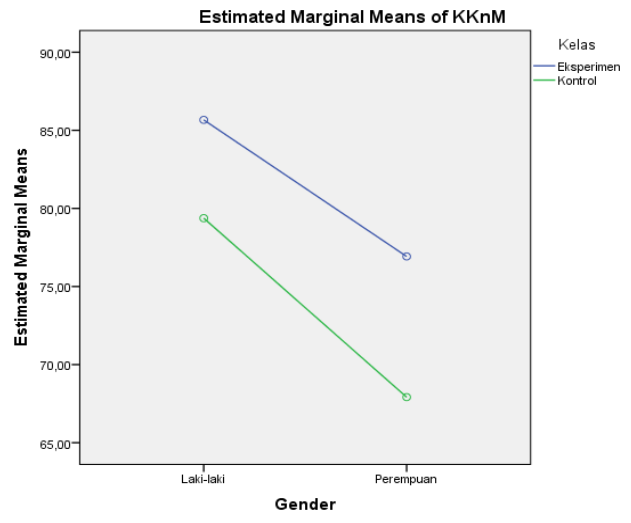

Gambar 2. Intraksi Pendekatan dengan Gender

Mosharafa: Jumal Pendidikan Matematika Volume 8, Nomor 3, September 2019 Copyright $\odot 2019$ Mosharafa: Jurnal Pendidikan Matematika 
simpulan bahwa tidak terdapat interaksi antara gender dengan pendekatan pembelajaran dalam membelajarkan KKnM siswa. Hal tersebut dapat dilihat lebih jelasnya pada gambar 2 out-put SPSS 20 berikut.

Dari gambar 2 dapat diperhatikan bahwa kurva kelas eksperimen tidak bersinggungan dengan kurva kelas kontrol dengan artian tidak terdapat interaksi antara perbedaan jenis kelamin (gender) dengan pendekatan pembelajaran dalam membelajarkan KKnM siswa.

\section{B. Pembahasan Hasil Penelitian}

Tidak terdapat interaksi antara KAM dengan pendekatan pembelajaran yang digunakan dalam membelajarkan KKnM siswa. Hal ini memberi arti KAM dengan pendekatan pembelajaran tidak memberi pengaruh secara bersamaan dalam membelajarkan kemampuan KKnM siswa. Hal senada juga diungkapkan dalam penelitian Fauzi (2013) tidak terdapat interaksi antara pendekatan pembelajaran (PPMG, PPMK, dan PB) dengan Kemampuan Awal Matematika (KAM) kategori baik, cukup dan kurang terhadap peningkatan KKnM siswa. Penelitian (Sari, 2015) Tidak terdapat interaksi antara pembelajaran dengan KAM siswa terhadap peningkatan KKnM siswa.

Perbedaan gender dengan pendekatan pembelajaran tidak berinteraksi dalam membelajarkan KKnM siswa. Dengan kata lain tidak terdapat interaksi antara gender dengan pendekatan pembelajaran dalam membelajarkan KKnM siswa. Hal senada juga diperoleh dari penelitian Nasution (2017) yaitu tidak terdapat interaksi antara pembelajaran (pendekatan realistik dan pembelajaran biasa) dengan gender (lakilaki dan perempuan) terhadap peningkatan kemampuan komunikasi dan self-efficacy matematis.

Tidak terdapatnya interaksi antara KAM dan gender dengan pendekatan pembelajaran dalam membelajarkan KKnM siswa juga diartikan bahwa interaksi antara pendekatan open-ended atau pendekatan konvensional dengan KAM tidak memberikan pengaruh secara bersama-sama yang signifikan dalam membelajarkan KKnM siswa. Selanjutnya KAM tidak berpengaruh dalam membelajarkan KKnM siswa sementara pendekatan pembelajaran merupakan aspek yang berpengaruh dalam membelajarkan KKnM siswa. Fauzi (2013); Sari (2015); Nasution (2017) mengungkapkan dengan tidak terdapatnya interaksi KAM atau gender dengan pendekatan pembelajaran maka perolehan kemampuan bermatematika siswa disebabkan oleh pendekatan pembelajaran yang digunakan.

Hal ini dapat diamati dalam pembelajaran yang dilaksanakan dengan pendekatan open-ended siswa terlihat antusias dalam pembelajaran, aktif dalam menemukan solusi dari permasalahan yang terdapat dalam lembar aktivitas siswa melalui diskusi dalam kelompok belajar, memberi jawaban dari permasalahan terbuka dengan beragam cara, membandingkan dan mendiskusikan 
jawaban melalui mempresentasikan hasil pemecahan masalah di depan kelas sehingga jawaban yang diperoleh siswa dalam kelompok belajar semakin bervasiasi, pembelajaran terlaksana dengan baik dengan tidak memandang perbedaan tingkat KAM dan perbedaan gender. Begitu juga pada kelas dengan pendekatan konvensional siswa aktif dalam memperhatikan penjelasan guru dalam pembelajaran dan mengerjakan soal latihan yang diarahkan guru tanpa memperhatikan tingkat KAM dan perbedaan gender.

Dengan demikian pendekatan pembelajaran yang digunakan memberi pengaruh dalam membelajarkan KKnM siswa selanjutnya tingkat KAM dan perbedaan gender tidak berpengaruh dalam membelajarkan KKnM siswa. Berdasarkan temuan dalam kegiatan pembelajaran dan analisis data penelitian disimpulkan bahwa tingkat KAM (tinggi, sedang dan rendah) atau perbedaan gender (laki-laki dan perempuan) dengan pendekatan pembelajaran open-ended atau konvensional tidak berinteraksi dalam membelajarkan KKnM siswa.

\section{Penutup}

Berdasarkan hasil dan pembahasan penelitian diperoleh simpulan bahwa tidak terdapat interaksi antara KAM (tinggi, sedang dan rendah) dengan pendekatan pembelajaran dalam membelajarkan KKnM siswa dan tidak terdapat interaksi antara gender (laki-laki dan perempuan) dengan pendekatan pembelajaran dalam 408 membelajarkan KKnM siswa. Selanjutnya berdasarkan simpulan penelitian diperoleh implikasi penelitian bahwa KKnM siswa tidak dipengaruhi oleh KAM dan pendekatan pembelajaran secara bersamaan atau gender dengan pendekatan pembelajaran secara bersamaan, namun KKnM siswa dipengaruhi oleh pendekatan pembelajaran yang diterapkan.

Berikut saran yang dapat disampaikan yaitu kepada guru mata pelajaran ketika menerapkan pembelajaran agar senantiasa memilih pendekatan pembelajaran yang tepat, karena pendekatan pembelajaran yang memberi pengaruh langsung dalam membelajarkan kemampuan bermatematika siswa, khususnya KKnM siswa. Selain itu kepada para peneliti untuk melakukan penelitian lanjutan dengan mengkaji faktor yang berinteraksi dengan pendekatan pembelajaran.

\section{UCAPAN TERIMA KASIH}

Penulis mengucapkan terimakasih kepada DRPM Kementerian Riset Teknologi Pendidikan Tinggi yang telah memberikan dana dalam pelaksanaan Penelitian Dosen Pemula (PDP) Bidang Fokus Sosial Humaniora-Seni Budaya-Pendidikan tahun anggaran 2018 dengan pendanaan tahun 2019.

\section{DAfTAR PUstaka}

Ahmad, M., \& Nasution, D. P. (2018). Analisis Kualitatif Kemampuan Komunikasi Matematis Siswa yang 
Diberi Pembelajaran Matematika Realistik. Jurnal Gantang, III(2), 8395.

https://doi.org/10.31629/jg.v3i2.471

Anandita, G. P. (2015). Analisis Kemampuan Koneksi Matematis Siswa SMP Kelas VIII pada Materi Kubus dan Balok. Jurusan Matematika F-MIPA UNS.

Andriani, Y. N., \& Madio, S. S. (2013). Perbandingan Kemampuan Berpikir Reflektif Antara Siswa yang Mendapatkan Pendekatan Open Ended dengan Konvensional. Mosharafa Jurnal Pendidikan Matematika, 2(2), 135-144.

Apriyono, F. (2014). Profil Kemampuan Koneksi Matematika Siswa SMP dalam Memecahkan Masalah Matematika Ditinjau dari Gender. Jurnal "Mosharafa," 5(3), 159-168. https://doi.org/10.31980/mosharafa. v5i2.271.

Fauzi, K. M. A. (2013). Kemampuan Koneksi Matematis Siswa dengan Pendekatan Pembelajaran Metakognitif di Sekolah Menengah Pertama. Jurnal Pendidikan Matematika Paradikma, 6(1), 49-74. https://doi.org/10.24114/paradikma. v6i1.1096

Latipah, E. D. P., \& Afriansyah, E. A. (2018). Analisis Kemampuan Koneksi Matematis Siswa Menggunakan Pendekatan Pembelajaran CTL dan RME. Matematika, 17(1). DOI: https://doi.org/10.29313/jmtm.v17i1. 3691

Maryani, N., Marlina, N., \& Amelia, R. (2019). Upaya Meningkatkan Kemampuan Berpikir Kreatif Siswa melalui Pendekatan Open Ended Materi Trigonometri. Jurnal Cendekia:
Jurnal Pendidikan Matematika, 3(1), 21-27.

https://doi.org/10.31004/cendekia.v3 i1.67

Mendikbud. (2014). Peraturan Menteri Pendidikan dan Kebudayaan Republik Indonesia Nomor 58 Tahun 2014 Tentang Kurikulum 2013 Sekolah Menengah Pertama/ Madrasah Tsanawiyah.

Nasution, D. P. (2017). Peningkatan Kemampuan Komunikasi dan Selfefficacy Matematis Siswa melalui Pendekatan Realistik di SMP N 4 Padangsidimpuan, Journal of Mathematics Paedagogic (JMP), II(1), 45-55.

NCTM. (2000). Principles and Standards for School Mathematics. Reston: VA NCTM.

Nugraha, A. A. (2018). Analisis Kemampuan Koneksi Matematis Siswa SMP pada Materi Sistem Persamaan Linear Dua Variabel (SPLDV). Suska Journal of Mathematics Education, 4(1), 59-64. https://dx.doi.org/10.24014/sjme.v4i 1.4579

Sabar, M. N. (2017). Effectiveness of Problem Based Learning Model (PBL) Setting Open Ended Approach in Mathematics Learning. Jurnal Daya Matematis, 5(3), 419-427. https://doi.org/10.26858/jds.v5i3.484 9

Salamah, F. N., \& Amelia, R. (2019). Upaya Meningkatkan Self Confidence Siswa SMK Menggunakan Pendekatan Open Ended. Jurnal Cendekia: Jurnal Pendidikan Matematika, 3(1), 28-33. https://doi.org/10.31004/cendekia.v3 i1.94

Saragih, S. (2007). Mengembangkan 
Kemampuan Berpikir Logis dan Komunikasi Matematika Siswa SMP melalui Pendekatan Matematika Realistik. Sekolah Pascasarjana UPI Bandung: Disertasi (Tidak diterbitkan).

Sari, L. N. I. (2015). Peningkatan Kemampuan Koneksi Matematis dan Berpikir Kreatif Siswa Melalui Pembelajaran Open Ended di SMP Muhammadiyah 03 Padangsidimpuan. Logaritma, II/(2), 70-83.

http://dx.doi.org/10.24952/logaritma .v3i02.1308

Sritresna, T. (2015). Meningkatkan Kemampuan Koneksi Matematis Siswa melalui Model Pembelajaran Cooperative-Meaningful Instructional Design (C-MID). Mosharafa Jurnal Pendidikan Matematika, 5(1), 38-47.

Sudirman, Cahyono, E., \& Kadir. (2018). Analisis Kemampuan Koneksi Matematis Siswa SMP Pesisir Ditinjau Dari Perbedaan Gender. Jurnal Pembelajaran Berpikir Matematika, 3(2), 11-22. http://dx.doi.org/10.33772/jpbm.v3i2 .5729

Sugiarti, S., \& Basuki. (2014). Pengaruh Model Pembelajaran Berbasis Masalah terhadap Kemampuan Koneksi Matematis Siswa Dalam Pembelajaran Matematika. Mosharafa Jurnal Pendidikan Matematika, 3(3), 151-158.

Sugiman. (2008). Koneksi Matematik Dalam Pembelajaran Matematika di Sekolah Menengah Pertama. Pythagoras, 4(1), 56-67. https://doi.org/10.21831/pg.v4i1.687 Sugiyono. (2016). Metode Penelitian Kuantitatif, Kualitatif, dan R\&D.
Bandung: Alfabeta.

Suherman, E., Turmudi, Suryadi, D., Herman, T., Suhendra, Prabawanto, S., ... Rohayati, A. (2001). Strategi Pembelajaran Matematika Kontemporer. Bandung: JICA-UPI.

\section{Riwayat Hidup PenUlis Roslian Lubis, S.Pd, M.Pd.}

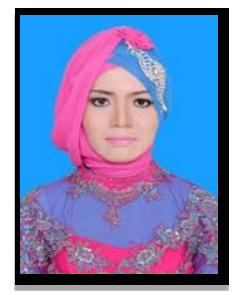

Lahir di Sibuhuan, 15 April 1984. Dosen Tetap Yayasan Institut Pendidikan Tapanuli Selatan. Studi S1 Pendidikan Matematika, STKIP Tapanuli Selatan, Padangsidimpuan, lulus tahun 2007; S2 Jurusan Teknologi Pendidikan Konsentrasi Pendidikan Matematika Universitas Negeri Padang, Padang, lulus tahun 2015.

\section{Toharuddin Harahap, S.Pd, M.M.}

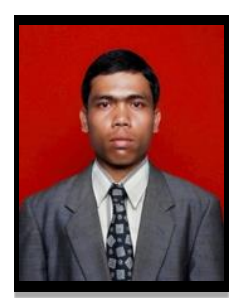
Lahir di Batang onang lama, 15 Juni 1989, Dosen Tetap Yayasan Institut Pendidikan Tapanuli Selatan. Studi S1 Pendidikan Ekonomi, STKIP Tapanuli Selatan. Padangsidimpuan, lulus tahun 2012; S2 Pendidikan Ekonomi Universitas Islam Sumatera Utara, Medan, lulus tahun 2015.

\section{Dwi Putria Nasution, S.Pd., M.Pd.}

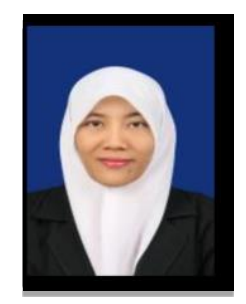

Lahir di Padangsidimpuan, 13 Mei 1988. Staf pengajar di SMA Negeri 2 Padangsidimpuan. Studi S1 Pendidikan Matematika STKIP Tapanuli Selatan, Padangsidimpuan, lulus tahun 2010; S2 Pendidikan Matematika UNIMED, Medan, lulus tahun 2016. 